\title{
A interpretação da Sagrada Escritura: eixo hermenêutico segundo J. Ratzinger - Papa Bento XVI
}

\author{
The Interpretation of Sacred Scripture: \\ Hermeneutic Axis According to J. Ratzinger \\ - Pope Benedict XVI
}

Maria de Lourdes Corrêa Lima

\section{Resumo}

O teólogo e cardeal J. Ratzinger tematizou em vários escritos a justa perspectiva na leitura bíblica: a superação, numa síntese superior, do dualismo entre método científico e visão de fé. A harmonia entre fé e razão é aplicada de modo coerente à leitura da Escritura e desenvolvidos seus corolários. Em seu ministério petrino, o Papa Bento XVI continuou este pensamento, agregando, dentro desta perspectiva, também algumas contribuições recentes da exegese. A sistematização dos pontos principais de seu pensamento sobre este tema pode fornecer importantes coordenadas e demonstrar sua relevância para a reflexão exegética e, consequentemente, para a teologia e a pastoral. São considerados escritos do Autor que tocam particularmente esta temática. Seguindo seus referenciais, a fé eclesial é capaz de ser mais bem compreendida, pelo homem atual, como caminho de sua plena realização.

Palavras chaves: Hermenêutica bíblica. Método exegético. Ratzinger Bento XVI.

\section{Abstract}

Cardinal and theologian J. Ratzinger has thematized through several 
writings the just perspective in the biblical reading: the overcoming, by means of a superior synthesis, of the dualism between the scientific method and a vision of faith. Harmony between faith and reason is applied in a coherent way to the reading of the Scriptures and its corollaries developed. In his Petrine ministry, Pope Benedict XVI continued this line of thought, adding, within this perspective, some recent contributions of exegesis. The systematization of the main points of his thinking on this theme can provide important coordinates and demonstrate their relevance for exegetical reflection and, consequently, for theology and pastoral. Here the writings of the Author that touches this subject in particular are considered. By following these referentials, ecclesial faith may be better understood by today's man, as a path to his full realization.

Keywords: Biblical hermeneutics. Exegetical method. Ratzinger - Benedict XVI.

\section{Introdução}

J. Ratzinger-Bento XVI é reconhecido pela profundidade e clareza de seu pensamento, pela abrangência de sua reflexão, por sua capacidade de análise da realidade e de orientação da fé. Chega, assim, a elaborar uma síntese teológica bem sucedida. Seu amplo conhecimento também filosófico lhe permite uma análise profunda das questões atuais, que, conjugada a uma perspectiva fortemente radicada no dado da fé, fornece elementos significativos para o anúncio convincente do Evangelho às diversas culturas $\mathrm{e}$ situações. Não sendo embora exegeta por formação, nosso Autor, certamente em virtude de sua compreensão da Escritura como pertencente ao núcleo da tarefa teológica, sempre deu grande importância ao tema da interpretação da Sagrada Escritura. Já nos seus primeiros anos, redigiu um comentário importante à então recentemente promulgada constituição Dei Verbum. E, no decorrer de todo seu labor como professor, bispo, cardeal responsável pela Congregação da Doutrina da Fé, até durante seu ministério petrino, o tema da Escritura sempre retornou com especial relevância.

A riqueza de seu ensinamento não é facilmente compendiada. Nesse sentido, a presente contribuição restringe sua finalidade a traçar os elementos que estruturam seu pensamento, indicando sua base e seus desdobramentos principais. Para tanto, além de seu comentário à constituição conciliar, seus 
três volumes sobre Jesus de Nazaré e sua exortação Verbum Domini, serão utilizados escritos esparsos: artigos, prefácios, discursos.

No primeiro momento, será apresentado o ponto de partida do pensamento de nosso Autor, que desembocará na avaliação por ele feita dos métodos históricos de exegese. Sua crítica será detalhada, uma vez que é em diálogo com a exegese crítica que é construída positivamente sua visão da natureza da metodologia exegética. Esta conduzirá a identificar as coordenadas para uma leitura cristã da Escritura, que dê conta da complexidade do dado bíblico, a um tempo humano e divino. Por fim, será analisada sua visão sobre o tema da razão e da fé no que tange à hermenêutica bíblica, com particular ênfase na questão da história e da perspectiva teológica.

Estas considerações demonstrarão a atualidade de sua reflexão e a possibilidade de fecundar ricamente a compreensão da Escritura em sua dimensão acadêmica e pastoral.

\section{Ponto de partida}

O ponto de partida do pensamento do Papa Ratzinger sobre a Sagrada Escritura repousa na clara afirmação de sua importância para a fé da Igreja. Disto resulta a ênfase dada ao tema de sua leitura e interpretação, com o que isto implica em termos de definição metodológica. Esta preocupação, presente já nos trabalhos do jovem teólogo, ${ }^{1}$ continuou por todo o seu caminho acadêmico e magisterial. A Escritura é uma realidade complexa, na medida em que é um texto antigo que veicula a Revelação divina. Deste seu caráter se depreende a necessidade da consideração de seu aspecto literário, sua localização histórica e a consideração da dimensão da fé que expressa.

J. Ratzinger considera que a questão em torno da interpretação da Escritura adquiriu dimensões notáveis, particularmente pelos progressos das ciências humanas e pela utilização de métodos científicos para o estudo de textos antigos, ${ }^{2}$ sobretudo a partir do final do século XIX. Estas perspectivas trouxeram questões

\footnotetext{
${ }^{1} \mathrm{Cf}$. seu comentário à Dei Verbum no $12^{\circ}$ volume do Lexikon für Theologie und Kirche (abreviado $L T h K)$ : RATZINGER, J. "Dogmatische Konstituition über die göttliche Offenbarung". In: RAHNER, K. (Org.). Lexikon für Theologie und Kirche. V. 12. Freiburg: Herder, 1964², pp. 498-528. 570-581.

${ }^{2}$ Cf., sobre este ponto, o Prefácio ao documento: PONTIFÍCIA COMISSÃO BÍBLICA. $A$ Interpretação da Bíblia na Igreja. Roma: Editrice Vaticana, 1993. Os documentos da Pontifícia Comissão Bíblica bem como todos os discursos, alocuções e encíclicas são encontrados no site oficial do Vaticano: www.vatican.va.
} 
novas e complexas quanto à hermenêutica dos textos bíblicos e sua adequabilidade ao estudo dos textos inspirados. Particular atenção mereceu o método históricocrítico, por ser o mais difundido e utilizado, também na exegese católica, no decorrer das últimas décadas, mesmo após o surgimento dos métodos sincrônicos de exegese. Por sua capacidade de ajudar na compreensão do texto, o método histórico-crítico foi aceito no trabalho teológico, embora suscitando debates, que ainda não chegaram, segundo nosso Autor, a uma solução unívoca. ${ }^{3}$ Neste debate participou a Santa Sé, dando orientações conforme as questões levantadas nos diferentes momentos deste processo. ${ }^{4} \mathrm{O}$ método recebeu cidadania na Igreja, oficialmente, com a encíclica Divino Afflante Spiritu (Pio XII, 1943). Atualmente, porém, afirma o Papa, não basta tomar esta encíclica como base para definição da metodologia exegética. Pois ela respondia a uma precisa situação acerca da leitura da Bíblia, em que uma exegese de cunho espiritualista era contraposta a uma aproximação dos textos bíblicos que considerasse seu lugar histórico original, linguística, cultual e teologicamente. ${ }^{5}$ Atualmente as questões que se colocam são em grande parte diversas.

A constituição conciliar Dei Verbum ${ }^{6}$ retomou os posicionamentos do Magistério anterior sobre a questão bíblica, o qual, sem rejeitar o uso das contribuições da ciência no estudo da Bíblia, procurou evidenciar seus aspectos positivos e chamar os exegetas a utilizá-las a partir de um olhar superior, dando forma a uma síntese cristã. Assumiu, assim, a perspectiva histórica, considerando-a uma das etapas da metodologia exegética, mas explicitou o que na encíclica de 1943 fora só indicado: a necessidade de a exegese completar o trabalho crítico com uma segunda etapa metodológica, a "leitura no Espírito" ( $D V$ 12). Com esta expressão, adquirida de Orígenes, ${ }^{7}$ a

\footnotetext{
${ }^{3}$ Cf. RATZINGER, J. "Prefácio" do documento A Interpretação da Bíblia na Igreja.

${ }^{4}$ Já, no final do século XIX, a encíclica Providentissimus Deus (Leão XIII, 1893) e, posteriormente, a Spiritus Paraclitus (Bento XV, 1920), assim como a Instrução Sancta Mater Ecclesia, da Pontifícia Comissão Bíblica (21.4.64), a Constituição Dogmática Dei Verbum, do Concílio Vaticano II (1965) e os posteriores documentos da Comissão Bíblica (A interpretação da Bíblia na Igreja, 1993; O povo hebraico e suas Sagradas Escrituras na Bíblia cristã, 2001). Ultimamente, a exortação pós-sinodal Verbum Domini (BENTO XVI. Exortação pós-sinodal Verbum Domini. Roma: Editrice Vaticana, 2010).

${ }^{5}$ Cf. RATZINGER, J. - BENTO XVI. Gesù di Nazaret. Milano: RCS Libri, 2007, p. 10.

${ }^{6}$ CONCÍlIO VATICANO II. Dei Verbum. Constituição dogmática sobre a revelação divina. Roma: Editrice Vaticana, 1965 (doravante abreviada $D V$ ).

${ }^{7}$ De principiis, I, Praef. 8: SC 252, 84, 86: cf. DE LA POTTERIE, I. "Il Concilio Vaticano II e la Bibbia”. In: DE LA POTTERIE, I. et alii (Org.), L'esegesi cristiana oggi. Casale Monferrato: Piemme, 1991, pp. 37-38.
} 
Dei Verbum intentou sublinhar a importância de a exegese chegar a identificar o sentido "oculto" por trás da expressão humana da Escritura: é este sentido que apresenta propriamente a Palavra que Deus quer comunicar. Tal princípio foi concretizado, no mesmo parágrafo do documento conciliar, em três princípios derivados: a unidade de toda a Escritura, a Tradição viva de toda a Igreja e a analogia da fé. Neste mesmo contexto, a Dei Verbum orienta para a valorização das conquistas antigas da tradição escriturística católica (patrística), unindoas aos progressos da metodologia e da ciência da interpretação. O teólogo J. Ratzinger insistiu nestes três elementos metodológicos ${ }^{8}$ e continuará a fazêlo enquanto cardeal prefeito da Congregação da Doutrina da Fé 9 e em seu ministério petrino. ${ }^{10}$ Tal afirmação vem agregada a uma pertinente crítica ao método-histórico crítico.

\section{A crítica ao método histórico-crítico}

Em diversas ocasiões nosso Autor indica que a metodologia histórica "é e permanece uma dimensão irrenunciável do trabalho exegético". ${ }^{11}$ Afirma mesmo que ele representa uma "necessidade absoluta", é "parte indispensável" do trabalho exegético. ${ }^{12}$

Ratzinger - Bento XVI explana os motivos de tal afirmação. A utilização do método histórico não pode ser reduzida somente a uma questão de escolha do estudioso, mas deve-se à "natureza intrínseca da teologia e da fé".13 Pois a fé judaica e cristã se baseia numa revelação que se radica na história, numa história real e não imaginada. "Para ela, o factum historicum não é uma chave simbólica que se possa substituir, mas sim fundamento constitutivo", ${ }^{14}$ pois

\footnotetext{
${ }^{8}$ Cf. RATZINGER, J. "Schriftauslegung im Widerstreit. Zur Frage nach Grundlagen und Weg der Exegese heute”. In: RATZINGER, J. (Org.). Schriftauslegung im Widerstreit. Freiburg im Breisgau - Basel - Wien: Herder, 1989, pp. 20. 34-44.

${ }^{9} \mathrm{Cf}$. O prefácio ao Documento A Interpretação da Bíblia na Igreja.

${ }^{10} \mathrm{Cf}$. as páginas que se seguem.

${ }^{11}$ RATZINGER, J. - BENTO XVI. Gesù di Nazaret, p. 11; cf. Discurso aos Bispos da Suiça, 7 de novembro de 2006.

${ }^{12}$ RATZINGER, J. “A relação entre o Magistério e a Igreja e a Exegese, a cem anos da constituição da Pontifícia Comissão Bíblica”. Disponível em: $<$ http://www.vatican.va/roman_curia/ congregations/cfaith/pcb_documents/rc_con_cfaith_doc_20021030_ratzinger_it.html $>$. Acesso em 10 de agosto de 2017 (Discurso por ocasião do centenário da Pontifícia Comissão Bíblica, 2003).

${ }^{13}$ RATZINGER, J. - BENTO XVI. Gesù di Nazaret, p. 11.

${ }^{14}$ RATZINGER, J. - BENTO XVI. Gesù di Nazaret, p. 11.
} 
Jesus Cristo é uma pessoa histórica real, não inventada. Não reconhecer este dado implicaria transformar radicalmente a própria natureza da fé cristã. Por isso é importante estudar o texto na sua literalidade, compreendendo sua língua em suas estruturas e modos de expressão, compreendendo suas fontes e formas literárias, enfim, seu ambiente de origem.

Visto que, na Palavra bíblica, Deus caminha para nós e nós para Ele, é preciso aprender a penetrar no segredo da língua, compreendê-la na sua estrutura e no seu modo de se exprimir. Assim, devido precisamente à procura de Deus, tornam-se importantes as ciências profanas que nos indicam as vias rumo à língua. ${ }^{15}$

O trabalho histórico e literário do exegeta é imprescindível, pois a Palavra de Deus que o texto expressa só é encontrada através das palavras humanas, situadas histórica e culturalmente. ${ }^{16}$

Com esta capacidade de decifrar o texto em seu momento inicial, o método histórico-crítico possibilitou a compreensão dos textos bíblicos no seu contexto histórico original e, portanto, no seu sentido primitivo. Como sua formulação típica, porém, surgiu eivada de pressupostos filosóficos racionalistas, torna-se necessário ir aos seus fundamentos, refletindo sobre eles e discernindo a possibilidade de separar filosofia e metodologia. J. Ratzinger sublinha que a exegese não pode pretender desenvolver um método que chegue a certezas ao nível das ciências naturais. Trata-se de estudar a Palavra, que possui um dinamismo próprio e que não pode ser reduzida aos aspectos históricos e literários. Por isso, o exegeta não pode partir de uma pré-compreensão racionalista, mas deve admitir que Deus pode manifestarse na história e que a história pode ter, em virtude disto, novos inícios. A lei da evolução do menos elaborado para o mais elaborado, do menos para o mais complexo, do aperfeiçoamento mecânico, não vale para esta realidade. A exegese deve estar acima da "razão pura". Do mesmo modo, não pode partir do pressuposto de que o homem não pode atingir a verdade. Em virtude da própria objetividade metodológica, o exegeta não pode forjar critérios para determinar o que pode ou não ser verdadeiro nos textos bíblicos, que contam

${ }^{15}$ BENTO XVI. "Discurso no encontro com o mundo da cultura no Collège des Bernardins, Paris, 12 de setembro de 2008". Disponível em: <http://w2.vatican.va/content/benedict-xvi/ pt/ speeches/ 2008/september/documents/hf_ben-xvi_spe_20080912_parigi-cultura.html>. Acesso em 20 de agosto de 2017. Cf. BENTO XVI. Verbum Domini, n. 32-33.

${ }^{16}$ Cf. BENTO XVI. Discurso no encontro com o mundo da cultura no Collège des Bernardins". 
com a característica fundante da inspiração. Se o ser humano é aberto para Deus, então deve esforçar-se para abrir-se ao próprio texto bíblico: seu ponto de partida é a Palavra da Bíblia - o que implica uma constante crítica de seu próprio pensamento e de seus critérios. ${ }^{17}$

Desta maneira, embora se apresentando como "objetivo", o método histórico-crítico na realidade traduz já um determinado ponto de vista sobre o que é ciência e sobre o que é a fé e sua possibilidade de averiguação. Tal problemática foi sempre claramente identificada por nosso Autor. Ele chama particularmente atenção para o fato que nenhuma leitura da Escritura é neutra. Sempre entram em jogo pressupostos do leitor. As próprias questões que são colocadas ao texto revelam uma pré-compreensão. Deste modo, enfatiza J. Ratzinger, é "necessário esclarecer ... qual seja o método justo de perguntar e de que forma é possível purificar o próprio perguntar". E ainda: "A mera objetividade do método histórico não existe. É simplesmente impossível excluir totalmente a filosofia, ou seja, a pré-compreensão hermenêutica". ${ }^{18}$ Surge assim, considerada a natureza do texto bíblico, a questão de qual seria o posicionamento seria o mais adequado para a interpretação da Escritura.

De outro lado, nosso Autor aceita o dado, já há anos adquirido, de que é possível distinguir, no método histórico, os pressupostos filosóficos e a metodologia propriamente dita, de modo que se pode utilizar sua metodologia sem pagar tributos às visões filosóficas que o inspiraram. Tal convicção foi condição de possibilidade para sua aceitação, pela exegese católica, como metodologia adequada para leitura dos textos bíblicos, ${ }^{19}$ desde que consideradas certas condições. Alguns perigos, no entanto, continuam inerentes a esta metodologia, cuja perspectiva intrínseca é a dimensão humana da palavra.

Primeiramente, o risco de enclausurar a Palavra de Deus no passado e, com isto, de não ser capaz de indicar sua relevância para a vida atual. Por sua própria natureza, o método histórico trabalha o texto como algo pertencente ao passado e o deixa no passado. Procura entender o que o texto quis comunicar na época em que foi escrito, dentro do código linguístico e cultural em que foi produzido e em suas finalidades circunstanciais. Embora este trabalho exegético possa levantar pontos de contato com a situação atual, o método enquanto tal não é capaz de trabalhá-los e, assim, tornar o texto relevante

\footnotetext{
${ }^{17}$ Cf. RATZINGER, J. "Schriftauslegung im Widerstreit”, pp. 34-36.

${ }^{18}$ RATZINGER, J. “A relação entre o Magistério e a Igreja e a Exegese, a cem anos da constituição da Pontifícia Comissão Bíblica".

${ }^{19}$ Cf. RATZINGER, J. "Schriftauslegung im Widerstreit”, p. 34.
} 
para o presente. ${ }^{20}$ Além disso, por interessar-se pelos textos em seu momento histórico, restringe-se a textos individuais, enfatizando as peculiaridades de cada um, ${ }^{21}$ fragmentando, assim, a Bíblia, de modo que a Escritura enquanto unidade lhe escapa. Ele pode descrever linhas de desenvolvimento de ideias, de tradições, que apontam para uma leitura unitária da Escritura, mas, em sua natureza própria, o método não atinge a Escritura como um todo. Além disso, procurando reconstruir as circunstâncias históricas, ultrapassa os dados textuais e cai inevitavelmente no campo hipotético: "a palavra se reduz a fragmentos", "desfaz-se em tantas fontes diversas", ${ }^{22}$ de forma que não é imediatamente perceptível sua relevância teológica. Neste contexto, as críticas ao método histórico-crítico se teceram sobretudo em duas perspectivas: sua incapacidade de oferecer um resultado seguro para a compreensão dos textos, uma vez que os resultados das pesquisas dificilmente concordavam entre si; e sua deficiência em alimentar a fé e a vida cristãs. Conjugado a estas duas dimensões está o fato da exigência de domínio de um complexo instrumental metodológico, que levou, em grande parte, a limitar a interpretação a um grupo restrito de especialistas. ${ }^{23}$

Estes aspectos desembocam no segundo grande risco inerente ao método: o de acentuar indevidamente o aspecto humano da Palavra, reduzindo o texto aos fatores imanentes e deixando de lado, por conseguinte, sua dimensão de expressão da fé. ${ }^{24}$ Ainda quando, no decorrer da metodologia, possam ser levantados elementos que apontem para um horizonte que transcende a palavra humana, por si mesmo o método não é capaz de elaborá-los. ${ }^{25}$

Considerado o conjunto destes fatores, fica evidente que tal metodologia precisa necessariamente de complementação. É parte integrante do trabalho exegético explicar o sentido do texto como "Palavra atual de Deus". ${ }^{26}$ Assim se expressa o Papa no prefácio ao primeiro volume de seu Jesus de Nazaré: o método histórico-crítico é

${ }^{20}$ Cf. RATZINGER, J. - BENTO XVI. Gesù di Nazaret, p. 12; Prefácio ao documento A Interpretação da Bíblia na Igreja.

${ }^{21}$ Cf. RATZINGER, J. - BENTO XVI. Gesù di Nazaret, p. 13.

22 BENTO XVI. "Discurso aos Bispos da Suíça, 7 de novembro de 2006". Disponível em: $<$ http://w2.vatican.va/content/benedict-xvi/pt/speeches/2006/november/documents/hf_ ben-xvi_spe_20061107_swiss-bishops.html>. Acesso em 15 de agosto de 2017.

${ }^{23}$ Cf. RATZINGER, J. Prefácio ao documento A Interpretação da Bíblia na Igreja.

${ }^{24}$ Cf. RATZINGER, J. Prefácio ao documento A Interpretação da Bíblia na Igreja.

${ }^{25}$ Cf. RATZINGER, J. - BENTO XVI. Gesù di Nazaret, p. 13.

${ }^{26}$ BENTO XVI. Verbum Domini, n. 33, citando A Interpretação da Bíblia na Igreja, III, C, 1. 
uma das dimensões fundamentais da exegese, mas não esgota a tarefa da interpretação para quem, nos textos bíblicos, vê a única Escritura Sagrada e nela crê como inspirada por Deus. ${ }^{27}$

Em outras palavras, o método é insuficiente e a exegese exige, pela própria natureza do texto (inspirado), a consideração propriamente teológica. ${ }^{28} \mathrm{Na}$ Verbum Domini, retomando seu discurso na aula do Sínodo, que reaparecerá também nas Propositiones, Bento XVI reconhece que, atualmente, a exegese bíblica trabalha "em alto nível" no que se refere ao uso do método histórico. Em vista disso, enfatiza a necessidade de os exegetas dedicaremse à formulação de passos também no que concerne ao aspecto teológico. Afirma: deve-se "exigir um estudo análogo [isto é, em alto nível] da dimensão teológica dos textos bíblicos". ${ }^{29}$ As duas dimensões não são inconciliáveis. A perspectiva teológica completa o método histórico-crítico, fazendo dele uma etapa importante do labor exegético e integrando-o na teologia. ${ }^{30}$

O Santo Padre dá exemplo prático desta complementariedade ao tratar a Escritura em seus livros sobre a pessoa de Jesus. Assim se expressa no primeiro volume de seu Jesus de Nazaré: "este livro pressupõe a exegese histórico-crítica e se serve dos seus resultados, mas quer ir além deste método, visando uma interpretação propriamente teológica". ${ }^{31}$

\section{Referenciais para a leitura teológica}

A relevância da leitura teológica se depreende já do fato que a Escritura possui duas faces, humana e divina. Uma exegese bíblica adequada deveria, então, atentar a estes dois níveis. ${ }^{32} \mathrm{O}$ nível teológico pode ser alcançado através dos três elementos indicados na Dei Verbum 12.

\footnotetext{
${ }^{27}$ RATZINGER, J. - BENTO XVI. Gesù di Nazaret, p. 12.

${ }^{28}$ Cf. RATZINGER, J. "A relação entre o Magistério e a Igreja e a Exegese, a cem anos da constituição da Pontifícia Comissão Bíblica".

${ }^{29}$ BENTO XVI. Verbum Domini, n. 34; Propositio, n. 26.

${ }^{30}$ Cf. RATZINGER, J. - BENTO XVI. Gesù di Nazaret, p. 15.

${ }^{31}$ RATZINGER, J. - BENTO XVI. Gesù di Nazaret, p. 409.

${ }^{32}$ Cf. BENTO XVI. "Intervenção na XIV Congregação geral do Sínodo, 14 de outubro de 2008”. Disponível em: <http://w2.vatican.va/content/benedict-xvi/pt/speeches/2008/october/ documents/hf_ben-xvi_spe_20081014_sinodo.html $>$. Acesso em $1^{\circ}$ de agosto de 2017 , retomada na Verbum Domini, n. 34.
} 


\subsection{Grande ênfase é dada, por nosso Autor, ao primeiro princípio teológico da} Dei Verbum: a unidade de toda a Escritura. O princípio da unidade da Escritura baseia-se na constatação de que os textos bíblicos foram formulados dentro de um processo de releitura, em que textos mais antigos eram relidos à luz de novas circunstâncias e aplicados, desenvolvidos, transformados e ampliados. ${ }^{33}$ Este processo é possibilitado pelo fato que uma palavra humana significativa traz em si potencialidades que ultrapassam seu momento histórico. ${ }^{34}$ $\mathrm{O}$ processo de releitura descobre num texto virtualidades latentes de sentido, que se tornam evidentes quando confrontadas com exigências de novas situações. Na Escritura, este processo é muitas vezes palpável, mas, considerado somente sob o aspecto das ciências humanas, as diferenças entre os diversos textos prevalecem sobre suas semelhanças e correlações, de modo que a unidade da Escritura não se torna evidente. A consideração literária e histórica percebe a multiplicidade. Somente se há um critério superior, de ordem teológica, é possível considerar a unidade apesar das diversidades. ${ }^{35}$

Este critério teológico tem seu fundamento no conceito mesmo de Revelação, segundo o qual Deus tem um plano de salvação que, mesmo comunicado aos homens progressivamente - e, portanto, manifestado sob múltiplos ângulos de vista -, é um único e idêntico plano. Isto implica que a Escritura, na multiplicidade das palavras e dos escritos, em suas diversas fases, veicula uma única Palavra de Deus, que comunica sua divina Pessoa e manifesta ao homem seu plano. Sendo Jesus Cristo o próprio Verbo encarnado e, portanto, a revelação máxima de Deus, Ele é o princípio último de unidade da Escritura. As múltiplas palavras recebem seu sentido, dentro do plano da Revelação, a partir da Palavra por excelência, o único $\log g o s,{ }^{36}$ o Verbo encarnado.

É nesse sentido que o Santo Padre fala de um "movimento interior do conjunto" ${ }^{37}$ que é mister considerar na interpretação de cada passagem da Escritura. Se o processo de Revelação, atestado na Escritura, é considerado a partir de Jesus Cristo, entende-se então que todo o Antigo Testamento caminhe para o Novo e que este esteja estreitamente ligado ao Antigo. Esta

\footnotetext{
${ }^{33}$ Cf. RATZINGER, J. - BENTO XVI. Gesù di Nazaret, p. 14.

${ }^{34}$ Cf. RATZINGER, J. - BENTO XVI. Gesù di Nazaret, p. 16.

${ }^{35}$ Cf. BENTO XVI. "Discurso no encontro com o mundo da cultura no Collège des Bernardins".

${ }^{36}$ Cf. BENTO XVI. "Discurso no encontro com o mundo da cultura no Collège des Bernardins".

${ }^{37}$ BENTO XVI. "Discurso no encontro com o mundo da cultura no Collège des Bernardins".
} 
"hermenêutica cristológica" é uma opção baseada na convicção de fé, mas esta convicção, por sua vez, ancora-se no fato que já no interior da Escritura tal processo estava em ato. Os textos bíblicos, sem perderem sua particularidade histórica, recebem, à luz de Cristo uma nova potencialidade. ${ }^{38}$

Consequentemente, não se pode enquadrar o trabalho exegético simplesmente na identificação do sentido literal, mas ele deve perguntar sobre o sentido espiritual. ${ }^{39}$ Isso não é possível se o trabalho exegético não abre os textos singulares ao conjunto da Escritura, numa dinâmica de transcendência da letra em direção ao espírito. Afirma o Santo Padre:

Não se trata de uma passagem automática e espontânea; antes, é preciso transcender a letra: "de fato, a Palavra do próprio Deus nunca se apresenta na simples literalidade do texto. Para alcançá-la, é preciso transcender a literalidade num processo de compreensão, que se deixa guiar pelo movimento interior do conjunto e, portanto, deve tornar-se também um processo de vida". ${ }^{40}$

E ainda: "única é a Palavra aquela para a qual somos chamados a transcender". ${ }^{41}$ Transcender a palavra individual na direção da única Palavra implica superar uma compreensão puramente histórica na direção da hermenêutica cristológica, segundo a qual todo o Antigo Testamento está orientado para Cristo. Esta "unidade interna de toda a Bíblia (é) ... critério decisivo para uma correta hermenêutica de fé". ${ }^{42}$

Daí resulta a profunda harmonia entre os Testamentos. Não só porque o Novo Testamento reconhece a sacralidade do Antigo e lhe dá valor comprobatório acima da simples razão humana, mas ainda porque utiliza muitas vezes a mesma linguagem e alude ou cita frequentemente o Antigo. Além disso, o próprio Novo Testamento afirma explicitamente o valor perene do Antigo (cf. $J o$ 10,35; Rm 15,4; ICor 10,11) e se apresenta como seu perfeito cumprimento, numa dinâmica que inclui elementos tanto de

\footnotetext{
${ }^{38}$ Cf. RATZINGER, J. - BENTO XVI. Gesù di Nazaret, p. 15.

${ }^{39}$ Por "sentido espiritual" entende-se o significado do texto bíblico considerado o evento pascal, cf. PONTIFÍCIA COMISSÃO BÍBLICA, A interpretação da Bíblia na Igreja, II B 2.

${ }^{40}$ BENTO XVI. Verbum Domini, n. 38, citando palavras do "Discurso no encontro com o mundo da cultura no Collège des Bernardins".

${ }^{41}$ BENTO XVI. Verbum Domini, n. 38 (em alemão: "Es ist ja ein einziges Wort, zu dem hin die Überschreitung erfolgen soll").

${ }^{42}$ BENTO XVI. Verbum Domini, n. 39.
} 
continuidade como de ruptura, de realização e superação. ${ }^{43}$ A releitura que o Novo Testamento faz do Antigo tem sua base e seu modelo no próprio Jesus. O Papa o demonstra, de modo tácito, na sua maneira de apresentar a pessoa de Jesus nos três volumes de seu Jesus de Nazaré. Dentre tantos elementos desenvolvidos pelo Papa, é suficiente considerar um exemplo que ilustra esta perspectiva: Jesus reza os Salmos e lhes confere plenitude de sentido. "Este processo de assunção e transposição [de sentido] ... é característico da unidade dos dois Testamentos, tal como Ele no-la ensina". ${ }^{4}$

Lido e vivido por Cristo, o Antigo Testamento recebe novos significados, a partir da compreensão que Ele mesmo tem do plano de Deus. A primeira geração cristã continuou este processo de releitura. Um caso paradigmático é exposto pelo Santo Padre ao tratar da crucifixão de Jesus. A realidade do Messias crucificado foi, para os apóstolos e os cristãos da primeira hora, um dado tão inesperado quanto incompreensível, sobretudo se considerada a expectativa, tantas vezes afirmada pelos textos veterotestamentários, da glória terrena do Filho de Davi. Com isto, o Santo Padre demonstra que foi a realidade de Jesus, sua maneira própria de entender sua vida e sua missão e, portanto, o modo como Ele interpretou as Escrituras, que exigiu dos discípulos uma releitura a partir da perspectiva do Mestre. Afirma o Santo Padre:

Com base em tal fato, era preciso ler a Escritura de modo novo (...). Partindo do inesperado, a Escritura se abriu de modo novo e, assim, o próprio fato adquiriu seu sentido. ${ }^{45}$

O Papa percebe aqui, portanto, uma perspectiva dialética: a pessoa de Cristo leva a reler à sua luz o Antigo Testamento e este então é capaz de lançar luz para a justa compreensão do fato.

Central nesta releitura é, dessa forma, o mistério pascal. A experiência das primeiras testemunhas, a convivência com Jesus e a guia do Espírito Santo foram os elementos que permitiram à primeira geração cristã suplantar a letra $\mathrm{e}$ chegar ao espírito: "À luz da ressurreição, à luz do dom de um novo caminhar com o Senhor, devia-se aprender a ler o Antigo Testamento de forma nova" ${ }^{46}$

\footnotetext{
${ }^{43}$ Cf. BENTO XVI. Verbum Domini, n. 40.

${ }^{44}$ RATZINGER, J. - BENTO XVI. Jesus de Nazaré. Parte II: Da entrada em Jerusalém até à Ressurreição. Cascais: Principia, 2011, p. 124.

${ }^{45}$ RATZINGER, J. - BENTO XVI. Jesus de Nazaré. Parte II, p. 200.

${ }^{46}$ RATZINGER, J. - BENTO XVI. Jesus de Nazaré. Parte II, p. 168.
} 
A partir destas considerações, o Antigo Testamento não pode ser substituído por nenhum outro conjunto de escritos. Ele é parte essencial da Revelação divina. Ao mesmo tempo, a hermenêutica cristológica é imprescindível. A relação entre os dois Testamentos é possível graças à tipologia, ou seja, na dinâmica de figura e realização. Com isto, o valor do Antigo Testamento não fica diminuído; ele "mantém seu próprio valor de Revelação, que Nosso Senhor veio reafirmar (cf. Mc 12,29-31)". ${ }^{47}$

Sugestiva é, nesse sentido, a citação que o Santo Padre faz de um texto de Orígenes numa de suas Catequeses das quartas-feiras:

Eu não chamo à Lei "Antigo Testamento", se a compreendo no Espírito. A Lei torna-se um "Antigo Testamento" só para aqueles que a desejam compreender carnalmente (...) para nós, que a compreendemos e aplicamos no Espírito e no sentido do Evangelho, a Lei é sempre nova, e os dois Testamentos são para nós um novo Testamento, não por causa da data temporal, mas pela novidade do sentido... Ao contrário, para o pecador e para quantos não respeitam o pacto da caridade, também os Evangelhos envelhecem. $^{48}$

No prefácio ao Documento da Pontifícia Comissão Bíblica sobre "O povo hebraico e suas Sagradas Escrituras na Bíblia cristã”, ${ }^{49}$ o então Cardeal Ratzinger sublinha que a unidade entre Antigo e Novo Testamento, baseada na pessoa de Jesus Cristo, "foi e permanece sendo o fundamento da decisão de fé na Igreja em seu conjunto". Não se trata de uma questão de menor importância, mas "os fundamentos mesmos do Cristianismo estão aqui em discussão", já que, sem o Antigo Testamento, o Novo "não teria sentido em si mesmo".

Por isso é importante, no trabalho exegético, como na teologia e na prática pastoral, evidenciar a íntima relação entre os dois testamentos. ${ }^{50}$

Este "movimento interior" da Escritura só pode ser percebido se considerado sob o prisma teológico e, portanto, numa leitura "no Espírito" (cf. $D V$ 12). O Santo Padre cita, a este propósito, os textos de 2Cor 3,6 ("A

\footnotetext{
${ }^{47}$ BENTO XVI. Verbum Domini, n. 41.

${ }^{48}$ Orígenes, Hom. Num. 9, 4, citado na "Catequese da Audiência Geral, 25 de abril de 2007". Disponível em: <http://w2.vatican.va/content/benedict-xvi/pt/audiences/2007/documents/hf ben-xvi_aud_20070425.html>. Acesso em 7 de junho de 2017.

${ }^{49}$ PONTIFÍCIA COMISSÃO BÍBLICA. O povo hebraico e suas Sagradas Escrituras na Bíblia cristã. Roma: Editrice Vaticana, 2001.
}

${ }^{50}$ Cf. BENTO XVI. Verbum Domini, 41. 
letra mata, mas o Espírito vivifica”) e 2Cor 3,17 (“Onde está o Espírito ... aí está a liberdade"), afirmando simultaneamente que a liberdade tem um critério: o Espírito do Senhor: "O Senhor é o Espírito e, onde está o Espírito do Senhor, aí está a liberdade” (2Cor 3,17). Com isto, abre-se a interpretação bíblica, para além da visão particular do leitor, ao princípio íntimo de unidade, o Cristo Jesus, numa síntese entre liberdade e vinculação com o critério superior, que ultrapassa não só o problema histórico e literário levantado pela exegese crítica, mas também toda e qualquer leitura fundamentalista. ${ }^{51} \mathrm{O}$ fundamentalismo não é uma alternativa válida à exegese crítica, pois ele - e nesse ponto ele se aproxima do método histórico-crítico - não atinge o sentido espiritual do texto. $\mathrm{O}$ centro do problema do fundamentalismo, que exige necessariamente sua rejeição, é o fato de ele se limitar ao que ele pensa ser a compreensão das palavras humanas (tomadas ainda em sua literalidade) e não chegar realmente à Palavra de Deus. ${ }^{52}$

Como perspectiva apta a corresponder ao princípio da unidade de toda a Escritura, Bento XVI aponta a exegese canônica, ${ }^{53}$ que visa ler o texto bíblico no contexto de toda a Escritura. Bento XVI reconhece que esta leitura ainda está em seus inícios, mas recomenda que se aprofundem os passos nesta direção. ${ }^{54}$ Evidentemente, a partir de seu ensinamento, uma leitura canônica que considerasse seriamente as perspectivas por ele delineadas não se poderia confundir com uma aproximação ingênua, acrítica, de textos. Mas, servindo-se dos grandes ganhos da exegese histórica, deveria ser capaz de reconstruir a lógica interna da Sagrada Escritura a partir da consideração dos diferentes textos dentro do conjunto. É isto, aliás, que nosso Autor desenvolve concretamente na sua forma de ler a Escritura que se deixa perceber nos três volumes de Jesus de Nazaré.

3.2. Estreitamente ligada à leitura na totalidade da Bíblia está a consideração do sujeito próprio da Escritura, tema que abre a questão da relação entre Escritura e Igreja e, com isto, entre Escritura e Tradição, Escritura e Magistério.

Bento XVI sublinha repetidas vezes a necessidade de uma correta identificação do sujeito da Escritura como um aspecto essencial da exegese

\footnotetext{
${ }^{51}$ Cf. BENTO XVI. "Discurso no encontro com o mundo da cultura no Collège des Bernardins".

${ }^{52}$ Cf. BENTO XVI. "Discurso no encontro com o mundo da cultura no Collège des Bernardins". ${ }^{53}$ Cf. RATZINGER, J. - BENTO XVI. Gesù di Nazaret, pp. 14-15; "Intervenção na XIV congregação geral do Sínodo dos Bispos"”.

${ }^{54}$ Cf. BENTO XVI. "Discurso aos Bispos da Suíça".
} 
teológica. A Escritura não surge somente da individualidade do autor (um ou vários) do texto; os autores radicam-se no povo de Deus, que os precede e de cuja experiência com Deus eles haurem. São partícipes de um povo que tem consciência de ser de modo particular ligado a Deus, que a ele dirige a palavra e o conduz. A Escritura expressa a fé do Povo de Deus e por isso só pode ser compreendida em referência a este Povo. ${ }^{55}$

"Para a Escritura, a relação com o sujeito 'povo de Deus' é vital", afirma Bento XVI. ${ }^{56}$ A relação se dá em duas direções: de um lado, a Escritura é livro normativo para o povo de Deus; de outro, a Escritura é realmente viva somente neste povo, em sua fé, que é a base sobre a qual ele se identifica como povo eleito. Isto significa que a Escritura só tem sua adequada leitura dentro desta comunidade viva. Nela a Escritura veio à luz, nela é vivida e por isso ela é que faz das Escrituras uma única Escritura. A Escritura é una a partir da interpretação da comunidade de fé, que se deixa conduzir por Deus ${ }^{57} \mathrm{Em}$ outros termos, a Palavra de Deus possui uma dimensão comunitária, eclesial, e isto traz consequências para sua interpretação:

A Palavra não leva apenas pela via individual de uma imersão mística, mas introduz na comunhão com todos os que caminham na fé. Por isso é preciso não só refletir sobre a Palavra, mas também lê-la de modo justo. ${ }^{58}$

Afirma-se, assim, o caráter fundamental da leitura da Escritura dentro da Tradição eclesial. Uma vez que a Escritura pertence à comunidade de fé, que a formulou e reconheceu como Palavra de Deus, a Igreja é o sujeito de direito para interpretá-la autenticamente.

A leitura dentro da Tradição da Igreja se justifica, segundo nosso Autor, também por outra via, que ele retoma da Dei Verbum. O tema da Escritura é tratado, na constituição conciliar, no interior da moldura mais ampla da Revelação divina. Superando a antiga teoria das duas fontes, a Dei Verbum apresenta Escritura e Tradição numa inter-relação orgânica, como meios através dos quais a Revelação, que é unitária, chega ao ser humano. Com isto, Escritura e Tradição podem ser consideradas somente em conjunto,

\footnotetext{
${ }^{55}$ Cf. RATZINGER, J. - BENTO XVI. Gesù di Nazaret, p. 17; Verbum Domini, n. 30.

${ }^{56}$ RATZINGER, J. - BENTO XVI. Gesù di Nazaret, p. 17.

${ }^{57}$ Cf. BENTO XVI. "Discurso aos Bispos da Suíça"; A relação entre o Magistério e a Igreja e a Exegese, a cem anos da constituição da Pontifícia Comissão Bíblica.

${ }^{58}$ BENTO XVI. "Discurso no encontro com o mundo da cultura no Collège des Bernardins".
} 
como testemunhas qualificadas da Palavra de Deus e numa relação de mútua dependência. ${ }^{59}$ Sob outro ponto de vista, porém, o conceito de Tradição é mais amplo do que o de Escritura, na medida em que a Escritura é também Tradição: dela nasceu, vive de seu dinamismo, vive ao transmitir a fé através das gerações cristãs e atualizá-la para as situações de cada época e cultura. A Escritura, no entanto, mantém uma importância central por ser texto escrito sob especial inspiração do Espírito Santo. J. Ratzinger observa que a Dei Verbum define a Escritura como Palavra de Deus, enquanto que, quanto à Tradição, prefere descrevê-la funcionalmente. Com esta diferenciação de formulação, é conferida à Escritura uma "precedência" frente à Tradição.

Bento XVI toca de passagem o tema da inspiração bíblica em seu primeiro volume de Jesus de Nazaré: "Se estamos convencidos de que as Sagradas Escrituras são 'inspiradas', amadurecidas de modo especial sob a guia do Espírito Santo...". ${ }^{60}$ Nestas poucas palavras, Bento XVI revela brevemente sua concepção de inspiração bíblica, numa formulação particularmente profunda e clara. Ao falar que as Escrituras passam por um processo de "amadurecimento", o Papa dá a entender que a inspiração bíblica é mais do que uma ação pontual; ele a concebe como um carisma mais amplo no tempo, que conduz o autor humano, pouco a pouco, com sua reflexão, suas tentativas de expressão, suas possíveis remodelações do escrito, a expressar o que realmente o Espírito Santo tem em vista: a Palavra de Deus.

A importância da Escritura se afirma ainda pelo fato que a Tradição é orientada à Escritura, enquanto deve, segundo a Dei Verbum 9, conservá-la, explicá-la e transmiti-la. ${ }^{61}$ Ou seja, o conceito de Tradição "supera a Escritura, apesar de ter nela o seu centro, a partir do momento em que a Escritura é, em primeiro lugar e por sua natureza, "tradição", ${ }^{62}$

Dentro da Tradição, seguindo as indicações da Dei Verbum, ${ }^{63}$ Bento XVI destaca o papel dos Santos Padres e apresenta como de inestimável valor, para recuperar a dimensão teológica da exegese, a consideração de

\footnotetext{
${ }^{59}$ Cf. $D V$ 9, comentado por J. Ratzinger: RATZINGER, J. "Dogmatische Konstituition über die göttliche Offenbarung”. In: $L T h K$, v. 12, p. 523.

${ }^{60}$ RATZINGER, J. - BENTO XVI. Gesù di Nazaret, p. 217.

${ }^{61}$ Cf. RATZINGER, J. "Dogmatische Konstituition über die göttliche Offenbarung”. In: J. $L T h K$, v. 12, p. 523.

${ }^{62}$ RATZINGER, J. "A relação entre o Magistério e a Igreja e a Exegese, a cem anos da constituição da Pontifícia Comissão Bíblica".

${ }^{63}$ Cf. $D V 8$ e 23.
} 
seus ensinamentos e suas coordenadas hermenêuticas. Pois primam pelo interesse religioso e pelo sentido de comunhão eclesial, manifestando a unidade existente entre sentido literal e espiritual. O Papa Ratzinger sublinha que não se trata de trabalhar, para investigação da face humana da Escritura, da mesma forma como os Padres, já que não dispunham dos instrumentais hoje conhecidos. Sem renunciar aos ganhos da história, da arqueologia, das ciências da linguagem, no entanto, é não só frutuoso mas ainda indispensável perseguir a mesma finalidade que eles perseguiram, qual seja, a compreensão do texto bíblico dentro da comunidade eclesial, da Tradição da Igreja, para edificação da fé, e com a perspectiva que tiveram: Cristo como ponto de unidade de toda a Escritura ${ }^{64}$ É nesse sentido que M. Reiser, cujo trabalho Bento XVI destaca como modelo de integração de leitura histórica e teológica ${ }^{65}$ chega a identificar o "alegórico" com o "cristológico" e a afirmar, na esteira dos Santos Padres, que Jesus Cristo é a chave de compreensão de toda interpretação alegórica. ${ }^{66}$

Os santos padres souberam unir estudo da letra do texto, fé (dogma) e Tradição. Dentre outros autores antigos que destaca, Bento XVI aponta o método de Orígenes como "inspirador" para uma exegese completa, que reúna a investigação da face humana e da face divina da Escritura: a busca, primeiramente, pelo sentido literal do texto; sua explicação detalhada, versículo por versículo; seu empenho por revelar o sentido "oculto" na letra, sua relevância moral (a vivência da Palavra) e espiritual (o que fala sobre Cristo), traduzindo sua mensagem para os ouvintes. ${ }^{67}$ Ao tratar da figura de São Jerônimo, chama a atenção para o critério fundamental de interpretação da Escritura formulado por este grande exegeta: a "sintonia com o Magistério da Igreja". Nosso Autor sublinha que esta sintonia não é uma exigência extrínseca ao texto bíblico, mas é a ele inerente, na medida em que a Bíblia é o livro do povo de Deus, do qual o Magistério é parte essencial, com especial função de servir à Palavra de Deus. ${ }^{68}$

\footnotetext{
${ }^{64}$ Cf. BENTO XVI. Verbum Domini, 37.

${ }^{65}$ Cf. RATZINGER, J. - BENTO XVI. Jesus de Nazaré. Parte II, p. 10.

${ }^{66}$ Cf. REISER, M. Bibelkritik und Auslegung der Heiligen Schrift. Tübingen: Mohr Siebeck, 2007, pp. 114-115.

${ }^{67}$ Cf. BENTO XVI. “Catequese da Audiência geral, 25 de abril de 2007”, sobre Orígenes.

${ }^{68}$ Cf. BENTO XVI. "Catequese da Audiência geral, 14 de novembro de 2007”. Disponível em: $<$ w2.vatican.va/content/benedict-xvi/pt/audiences/2007/documents/hf_benxvi_aud_20071114. Html $>$. Acesso em 14 de junho de 2017, sobre São Jerônimo.
} 
A questão da relação entre Escritura e Magistério é tocada diversas vezes nos escritos de nosso Autor. Foi especialmente tratada em seu discurso por ocasião do centenário da Pontifícia Comissão Bíblica, pelo então Cardeal J. Ratzinger. Nosso Autor reconhece que determinadas decisões da Comissão Bíblica nos inícios do século passado "alargavam demasiadamente o âmbito das certezas que a fé pode garantir". No entanto, com não menos clareza, afirma que a fé tem algo a dizer sobre a interpretação bíblica e, com isto, o Magistério tem também seu papel no que tange a orientar e chamar a atenção para que a interpretação não perca a especificidade do dado bíblico como expressão de uma fé que o precede e acompanha.

Tal perspectiva, esclarece Ratzinger, não limita erroneamente a liberdade do exegeta, mas revela suas "condições intrínsecas", que são assim elencadas:

a escuta atenta, conhecimento dos limites dos vários caminhos, plena seriedade da ratio, mas também espontaneidade em limitar-se e em superar-se no pensar e no viver juntamente com o sujeito que nos garante os diversos escritos da Antiga e da Nova Aliança como uma única obra, a Sagrada Escritura. ${ }^{69}$

3.3. Todas essas reflexões evidenciam a importância do terceiro princípio colocado pela Dei Verbum 12 para a exegese teológica, a analogia fidei, e simultaneamente o expressam.

A negligência ou ausência destes princípios no labor exegético não fica sem graves consequências, afirma o Papa Ratzinger. Três aspectos são especialmente postos em relevo. Primeiramente, o fato de a Escritura reduzirse a um texto do passado, um documento marcado religiosa e culturalmente, pura literatura ou história. Em segundo lugar, o estabelecimento de um fosso entre exegese científica e leitura espiritual, com suas consequências para a pregação, a pastoral em geral, a vida espiritual e o anúncio da fé. ${ }^{70}$ Por fim, como consequência, uma hermenêutica positivista e imanentista da Escritura, que opõe fé e razão. Por sua importância, este aspecto será considerado com mais detalhes na próxima seção.

\footnotetext{
${ }^{69}$ RATZINGER, J. "A relação entre o Magistério e a Igreja e a Exegese, a cem anos da constituição da Pontifícia Comissão Bíblica".

${ }^{70}$ Cf. BENTO XVI. "Intervenção na XIV Congregação geral do Sínodo".
} 


\section{Relação entre metodologia científica e perspectiva da fé}

Da consideração dos princípios teológicos da interpretação da Escritura resulta a necessidade de se esclarecer a distinção e a inter-relação dos dois âmbitos em que se move a exegese: científico (histórico-literário) e teológico.

As duas dimensões, afirma nosso Autor, não podem ser consideradas antagônicas, pois daí derivaria o perigo de dualismo, com suas consequências não só a nível exegético, mas ainda teológico, pastoral e espiritual. Como não há antagonismo entre fé e razão, mas dimensões próprias de investigação, que não se excluem mas se complementam, assim também os dois níveis de estudo exegético devem ser desenvolvidos em harmonia. ${ }^{71}$

Quando não se ultrapassa o nível de investigação humana, abrindo a perspectiva teológica, "seu lugar acaba inevitavelmente ocupado por outra hermenêutica, uma hermenêutica secularizada, positivista, cuja chave fundamental é a convicção de que o Divino não aparece na história humana". ${ }^{72}$ Tal perspectiva significa a redução do dado bíblico ao aspecto histórico, literário, cultural. Em outras palavras, a aplicação pura e simples dos métodos científicos não significa neutralidade na investigação: sempre há, já de antemão, pressupostos filosóficos. Se não se utilizam os critérios teológicos, governam a compreensão os pressupostos historicistas que cunharam o método histórico-crítico. Uma hermenêutica secularizada afeta fortemente a fé, pois levanta dúvidas sobre seus elementos fundamentais e sobre sua realidade histórica (por exemplo, o nascimento de Jesus da Virgem Maria, a instituição da Eucaristia, a realidade da ressurreição de Jesus). "Científico" (neutro) não é analisar o texto conforme o método histórico, mas analisá-lo com um método que esteja de acordo com o objeto que é estudado. ${ }^{73}$ Como tal, a leitura na fé não é extrínseca à Escritura, não é contrária ao caráter objetivo da interpretação.

Bento XVI distingue dois níveis da questão. Primeiramente, sobre o âmbito de competência das ciências históricas e literárias no que concerne à Escritura, ou, dito de outro modo, sobre a competência do método histórico-crítico para interpretar a Escritura. Ele chama a atenção para a necessidade de clareza acerca de suas fronteiras: onde ele começa, do quê pode dar conta e onde deve terminar. Com isto, toca a questão da justa

\footnotetext{
${ }^{71}$ Cf. BENTO XVI. Verbum Domini, 36.

${ }^{72}$ BENTO XVI. Verbum Domini, 35.

${ }^{73}$ Cf. BENTO XVI. Verbum Domini, 35.
} 
relação entre fé e razão aplicada à hermenêutica bíblica. Para esclarecê-la, nosso Autor parte da constatação de que o "racional" não pode ser limitado ao tangível, ao material. Analogamente, o que é "histórico" também não pode ser reduzido ao verificável segundo a razão positiva. Admitir uma incompatibilidade entre fé e história tem como consequência desencarnar a fé. Ela se torna um conhecimento puramente subjetivo e no campo das ideias, torna-se "gnose", não correspondendo ao dado bíblico, que exige a referência a acontecimentos reais. ${ }^{74}$

Para a revelação judaica e cristã, Deus não é uma realidade extrínseca à vida humana, mas Alguém que se manifesta na história. A história é uma dimensão constitutiva da fé judaica e cristã, pois é não somente palco da ação humana, mas interação entre Deus e o homem. Por isso os dados fundantes da fé devem ser afirmados frente a uma visão histórica positivista.

Que Jesus em tudo o que é essencial tenha sido efetivamente aquele que nos mostram os Evangelhos, não é de modo algum um pressuposto histórico, mas um dado de fé. Objeções que nos queiram convencer do contrário não são expressão de um efetivo conhecimento científico, mas são uma sobre-estimação arbitrária do método. ${ }^{75}$

Bento XVI põe em relevo, de modo especial, a importância da dimensão histórica da fé cristã e a defende, sempre considerada a forma literária utilizada pelos textos:

Não foram as palavras da Escritura que suscitaram o relato dos fatos, mas sim os fatos, que num primeiro tempo eram incompreensíveis, que levaram a uma nova compreensão da Escritura. (...)

Esta concordância (...) entre fato e palavra não só determina a estrutura das narrações do acontecimento da Paixão (e dos Evangelhos em geral), mas também é constitutiva da própria fé cristã. (...)

Onde esta conexão é desfeita, dissolve-se a própria estrutura basilar da fé cristã. ${ }^{76}$

\footnotetext{
${ }^{74}$ Cf. RATZINGER, J. "A relação entre o Magistério e a Igreja e a Exegese, a cem anos da constituição da Pontifícia Comissão Bíblica”.

${ }^{75}$ Cf. RATZINGER, J. "A relação entre o Magistério e a Igreja e a Exegese, a cem anos da constituição da Pontifícia Comissão Bíblica”.

${ }^{76}$ RATZINGER, J. - BENTO XVI. Jesus de Nazaré. Parte II, p. 168.
} 
O Papa Ratzinger desenvolve de modo muito esclarecedor este aspecto também quanto ao Antigo Testamento, que oferece, sem dúvida, grandes dificuldades do ponto de vista histórico. Nosso Autor reconhece ser a crítica literária capaz de mostrar que há textos muito tardios e tão uniformes (em termos de vocabulário e teologia) que não podem ser considerados discurso de um determinado personagem, por exemplo, Moisés (assim nos livros do Êxodo e do Deuteronômio). Também muitos fatos devem ser interpretados considerando-se os gêneros literários utilizados e não simplesmente como crônica histórica. Assim, por exemplo, as pragas do Egito podem ser, em parte significativa, explicadas naturalmente; a tenda do deserto é apresentada à luz do que foi posteriormente o templo de Jerusalém; as leis apresentadas como dadas no deserto expressam uma sociedade posterior; os mandamentos podem ou não ter origem em Moisés. No entanto, sob todas estas formas de expressão, há um núcleo de fé, a convicção de que Deus chamou um povo, conduziu-o por meio de um mediador, libertando-o de uma opressão social estrangeira, fez com ele uma aliança... Como, porém, o antigo Israel não tinha como garantir a historicidade de todos os dados, pois não dispunha de fontes documentais no sentido moderno e vivia basicamente da tradição oral, que só bem tardiamente foi posta por escrito, o passado pode ter sido reconstruído com dados anacrônicos, de forma que as lacunas que a tradição apresentava foram preenchidas com novos dados, ou os eventos foram reinterpretados (releitura). Isto não invalida a existência de um dado fundante na origem, radicado na história - dado que foi apresentado de maneira a evidenciar seu aspecto religioso e formativo da fé. ${ }^{77}$

Diferente disto são questões não essenciais e também detalhes de dados essenciais, cuja dimensão e valor histórico devem ser avaliados dentro de uma hermenêutica responsável, que conjugue adequadamente análise literária, investigação histórica e critérios de fé.

Abre-se aqui o segundo nível da questão: a competência da razão diante dos dados da fé e a abertura da fé à razão e da razão à fé. Nosso Autor chama a atenção para o fato que o próprio conhecimento científico tem limites e não é totalmente objetivo, pois sempre reflete também um determinado modo de ver a realidade e a capacidade de quem o pensa. Se é assim, não há contraposição entre fé e razão: não só porque o dado da fé não é irracional, mas porque, da parte de ambos, há pressupostos

${ }^{77}$ Cf. BENTO XVI. Verbum Domini, 35. 
que influenciam o conhecimento. Negar o dado da fé não significa ser mais objetivo cientificamente, mas revela simplesmente um pressuposto filosófico que exclui de antemão a possibilidade de uma dimensão da realidade. Dessa forma, se a Escritura é definida a partir da Palavra divina, conhecida e comunicada por uma comunidade (o povo de Deus), isto deve ser considerado na compreensão objetiva de seus escritos. ${ }^{78}$

Fé e razão apresentam aspectos próprios que exigem metodologias próprias. Não se opõem, mas se complementam. Isto significa que a exegese bíblica é fundamentalmente uma disciplina teológica, que abarca dois âmbitos, correspondentes aos níveis inerentes à natureza do texto bíblico. Ambos são aspectos do estudo exegético e devem integrá-lo harmoniosamente. ${ }^{79}$ Para dar espaço à leitura da fé, por conseguinte, não é necessário nem mesmo possível abrir mão de um trabalho científico.

Em síntese, devem ser claramente definidas, no estudo da Escritura, as competências dos métodos utilizados e considerada adequadamente a relação entre ciência e fé. A ausência desta distinção e complementariedade cria um fosso entre Escritura e teologia, entre Escritura e vida espiritual, incluída aqui também a pastoral. No que tange à teologia, uma exegese que se limite às palavras humanas é incapaz de integrar o labor teológico a partir de dentro. Afirma o Papa Ratzinger:

Onde a exegese não é teologia, a Escritura não pode ser a alma da teologia e, vice-versa, onde a teologia não é essencialmente interpretação da Escritura na Igreja, esta teologia já não tem fundamento. ${ }^{80}$

A dissociação entre exegese e teologia, por sua vez, acarreta graves consequências para a vivência da fé e para a missão evangelizadora:

Para a vida e para a missão da Igreja, e para o futuro da fé, é absolutamente necessário ultrapassar este dualismo entre exegese e teologia. A teologia bíblica e a teologia sistemática são duas dimensões de uma única realidade, que denominamos teologia. ${ }^{81}$

\footnotetext{
${ }^{78}$ Cf. RATZINGER, J. "A relação entre o Magistério e a Igreja e a Exegese, a cem anos da constituição da Pontifícia Comissão Bíblica”.

${ }^{79}$ Cf. BENTO XVI. Verbum Domini, 36.

${ }^{80}$ BENTO XVI. "Intervenção na XIV Congregação Geral do Sínodo", citada em Verbum Domini, 35.

${ }^{81}$ BENTO XVI. "Intervenção na XIV Congregação Geral do Sínodo".
} 
Ou ainda: "Da relação fecunda entre exegese e teologia depende, em grande parte, a eficácia pastoral da ação da Igreja e da vida espiritual dos fiéis". ${ }^{82}$

Só uma exegese que ultrapassa o histórico e chega ao teológico pode, por conseguinte, ser útil à fé eclesial. Devido à posição central que a Escritura ocupa na formulação da fé e na sua vivência, o trabalho exegético põe sempre em jogo a própria vida e missão da Igreja. Por isso é necessário "desenvolver uma exegese não somente histórica, mas também teológica". ${ }^{83}$ Somente se há integração destes dois níveis a exegese pode contribuir para a vivência da fé, da qual depende a vitalidade da comunidade eclesial e a autenticidade do anúncio. ${ }^{84}$ Se a Igreja é, por definição, "uma comunidade que escuta e anuncia a Palavra de Deus", ${ }^{85}$ só a partir de sua escuta (que implica sua recepção como Palavra de Deus e não simples texto humano) pode ter lugar o anúncio. Pois a Escritura não é simples conjunto de palavras, mas traz em si a realidade do próprio Cristo: "Cristo vive nas Sagradas Escrituras". ${ }^{86}$

Nesse contexto, Bento XVI divisa a importância da adequada formação de exegetas e anunciadores da Palavra. No que tange ao âmbito próprio da formação exegética, chama a atenção para a necessidade de "ampliar a formação dos futuros exegetas..., em vista de abrir realmente os tesouros da Escritura ao mundo de hoje e a todos nós". ${ }^{87}$ É urgente formar professores capazes de, no ensino da Escritura, integrar sua face divina e humana, de modo que, "paralelamente à exegese histórico-científica seja feita deveras uma introdução à Escritura viva, como Palavra de Deus atual", ${ }^{88}$ de modo que se torne possível um real "imergir-se interiormente na presença da Palavra". ${ }^{89}$

\footnotetext{
${ }^{82}$ BENTO XVI. Verbum Domini, 31.

${ }^{83}$ BENTO XVI. "Intervenção na XIV Congregação Geral do Sínodo".

${ }^{84}$ Cf. BENTO XVI. "Discurso no encontro com o mundo da cultura no Collège des Bernardins".

${ }^{85}$ BENTO XVI. BENTO XVI. "Discurso aos participantes do Congresso Internacional por ocasião do $40^{\circ}$ aniversário da Constituição dogmática sobre a divina revelação, Dei Verbum, 16 de setembro de 2005". Disponível em: <http://w2.vatican.va/content/benedict-xvi/pt/ speeches/2005/september/documents/hf_ben-xvi_spe_20050916_40-dei-verbum.html>. Acesso em 8 de agosto de 2017.

${ }^{86}$ BENTO XVI. "Discurso aos participantes do Congresso Internacional por ocasião do $40^{\circ}$ aniversário da Constituição dogmática sobre a divina revelação, Dei Verbum".

${ }^{87}$ BENTO XVI. "Intervenção na XIV Congregação Geral do Sínodo".

${ }^{88}$ BENTO XVI. "Discurso aos Bispos da Suíça".

${ }^{89}$ BENTO XVI. "Discurso aos Bispos da Suíça".
} 


\section{Considerações conclusivas}

O percurso acima realizado evidencia a unidade de pensamento entre o teólogo e cardeal J. Ratzinger e o Papa Bento XVI. Há uma total coerência de pensamento, que vem desde o jovem Ratzinger até os dias atuais, com o desenvolvimento orgânico de uma visão da Escritura que considera em profundidade, para além da superfície imediatamente tangível, as grandes questões envolvidas nesse assunto. Tal impostação, desenvolvida com grande perspicácia intelectual, permite superar oposições, por uma reflexão que escava os fundamentos e chega a formular uma síntese superior. Sua base radica-se na clareza sobre a teologia como ciência da fé, sobre o conceito de revelação, sobre a unidade entre fé e razão, elementos que, aplicados à hermenêutica da Escritura, conduzem a definir a exegese como uma disciplina teológica.

Nosso autor afirma a importância e a necessidade da exegese bíblica, com sua face histórica, na Igreja e no mundo. Rejeita, nesse sentido, totalmente o fundamentalismo, que, sob o pretexto de encontrar o verdadeiro sentido do texto bíblico, em realidade se distancia do sentido autêntico dos textos e ignora a dimensão encarnatória da Revelação. Se Deus se revelou utilizando os traços de linguagem e cultura do povo e das pessoas a quem se dirigiu e a quem confiou a tarefa de pôr por escrito sua Palavra, só podemos compreender esta Palavra se consideramos os condicionamentos ambientais e culturais através dos quais nos foi transmitida.

Igualmente, porém, afirma que não se pode pretender que o método histórico-crítico seja absoluto e que o exegeta deve estar consciente dos limites e perigos desta metodologia. De fato, por deter-se no significado original, o método histórico descura o aspecto dinâmico dos textos e a possibilidade de estes assumirem novos sentidos no decorrer de seu desenvolvimento. Além disso, caso pare em questões de fontes e de composição literária, não chega realmente a realizar a tarefa da exegese. Precisa, assim, ser completado pela perspectiva propriamente teológica, que corresponde à natureza do texto bíblico como mediador, em palavras humanas, da Palavra de Deus. Aqui, o pensamento de Ratzinger - Bento XVI é construído sobre os pilares colocados pela Dei Verbum, particularmente no que tange à "leitura no Espírito" e aos três princípios que a possibilitam.

Atento aos novos desenvolvimentos de métodos e abordagens, nosso Autor afirma em diversos escritos a utilidade da abordagem canônica, que, 
enquanto projeto, corresponderia ao princípio hermenêutico da unidade da Escritura. Reconhece, porém, a necessidade de se aprofundar esta abordagem, quiçá, acrescentaríamos, indicando uma metodologia capaz de analisar a unidade de toda a Escritura a partir de categorias propriamente bíblicas e não importadas de sistemas dependentes de perspectivas subjetivas.

Em outros termos, a exegese não pode ser reduzida a uma disciplina simplesmente histórica, mas tem como escopo o aprofundamento da fé. Esta ordenação à fé implica que o estudo científico, mantido em sua autonomia, é meio e não fim em si mesmo. As etapas metodológicas devem servir ao escopo último da exegese e devem ser avaliadas, em sua necessidade e medida, pelo critério de coerência com o conteúdo da totalidade da Escritura.

Concluindo, o Papa Ratzinger apresenta, quanto à questão da hermenêutica da Sagrada Escritura, uma síntese teológica apta a oferecer aos leitores da Bíblia orientações seguras para que ela seja realmente instrumento de encontro com a Revelação divina. Aos exegetas em particular, proporciona ricos elementos de reflexão a serem transformados numa metodologia que dê conta das exigências da exegese como disciplina teológica. Bento XVI deixa esta tarefa aos estudiosos. Contudo, no modo de ler a Escritura que transparece em seus escritos, embora sem desenvolver um trabalho estritamente exegético, demonstra concretamente sua concepção hermenêutica. Utiliza os resultados da exegese histórica, acolhendo-os sob o crivo da compreensão teológica da Escritura, de acordo com as orientações da Dei Verbum e em estreita conjunção entre fé e razão. Com isto, é capaz de desenvolver as virtualidades da Palavra, evidenciando seu significado humano e teológico, e chegar, assim, a anunciá-la de modo convincente, de modo a interpelar a razão humana e a aprofundar a fé, evidenciando sua relevância para a vida atual.

A Escritura, lida segundo esta orientação, é real caminho de humanização. "A Palavra de Deus... indica ao homem os caminhos da vida e revela-lhe os segredos da santidade", é "estímulo e fonte da vida cristã para todas as situações e para cada pessoa" "90, afirma.

Com esta orientação, de fato a Palavra se torna meio de comunhão com Deus, escopo último da vida humana, individual e comunitariamente: "é a

\footnotetext{
${ }^{90}$ BENTO XVI. Audiência Geral, 14 de novembro de 2007, sobre São Jerônimo.
} 
Sagrada Escritura que nos oferece a guia para ... o verdadeiro humanismo"91. E ainda:

A palavra bíblica tem a sua origem em um passado que é real, mas não somente num passado; vem também da eternidade de Deus. Ela nos conduz à eternidade de Deus, passando, porém, através do tempo, que compreende o passado, o presente e o futuro ${ }^{92}$.

\section{Referências bibliográficas}

BENTO XVI. "Catequese da Audiência geral, 14 de novembro de 2007". Disponível em: <w2.vatican.va/content/benedict-xvi/pt/audiences/2007/ documents/hf_benxvi_aud_20071114. Html $>$. Acesso em 14 de junho de 2017.

BENTO XVI. “Catequese da Audiência Geral, 25 de abril de 2007”. Disponível em: $\quad<$ http://w2.vatican.va/content/benedict-xvi/pt/audiences/2007/ documents/hf_ben-xvi_aud_20070425.html $>$. Acesso em 7 de junho de 2017.

BENTO XVI. "Discurso aos Bispos da Suíça, 7 de novembro de 2006". Disponível em: $\quad<$ http://w2.vatican.va/content/benedict-xvi/pt/ speeches/2006/november/documents/hf_ben-xvi_spe_20061107_swissbishops.html>. Acesso em 15 de agosto de 2017.

BENTO XVI. "Discurso aos participantes do Congresso Internacional por ocasião do $40^{\circ}$ aniversário da Constituição dogmática sobre a divina revelação, Dei Verbum, 16 de setembro de 2005". Disponível em: $<$ http://w2.vatican.va/content/benedict-xvi/pt/speeches/2005/september/ documents/hf_ben-xvi_spe_20050916_40-dei-verbum.html>. Acesso em 8 de agosto de 2017.

BENTO XVI. "Discurso no encontro com o mundo da cultura no Collège des Bernardins, Paris, 12 de setembro de 2008”. Disponível em: $<$ http:// w2.vatican.va/content/benedict-xvi/pt/ speeches/ 2008/september/ documents/hf_ben-xvi_spe_20080912_parigi-cultura.html>. Acesso em 20 de agosto de 2017.

\footnotetext{
${ }^{91}$ BENTO XVI. Audiência Geral, 14 de novembro de 2007.

${ }^{92}$ RATZINGER, J. Prefácio ao documento A Interpretação da Bíblia na Igreja.
} 
BENTO XVI. Exortação pós-sinodal Verbum Domini. Roma: Editrice Vaticana, 2010.

BENTO XVI. “Intervenção na XIV Congregação geral do Sínodo, 14 de outubro de 2008". Disponível em: <http://w2.vatican.va/content/benedict-xvi/pt/ speeches/2008/october/documents/hf_ben-xvi_spe_20081014_sinodo. html $>$. Acesso em $1^{\circ}$ de agosto de 2017.

CONCÍLIO VATICANO II. Dei Verbum. Constituição dogmática sobre a revelação divina. Roma: Editrice Vaticana, 1965.

DE LA POTTERIE, I. "Il Concilio Vaticano II e la Bibbia". In: DE LA POTTERIE, I. et alii (Org.). L'esegesi cristiana oggi. Casale Monferrato: Piemme, 1991.

PONTIFÍCIA COMISSÃO BÍBLICA. A Interpretação da Bíblia na Igreja. Roma: Editrice Vaticana, 1993.

PONTIFÍCIA COMISSÃO BÍBLICA. O povo hebraico e suas Sagradas Escrituras na Bíblia cristã. Roma: Editrice Vaticana, 2001.

RATZINGER, J. - BENTO XVI. Gesù di Nazaret. Milano: RCS Libri, 2007.

RATZINGER, J. - BENTO XVI. Jesus de Nazaré. Parte II: Da entrada em Jerusalém até à Ressurreição. Cascais: Principia, 2011.

RATZINGER, J. - BENTO XVI. Jesus de Nazaré. Parte III: A infância de Jesus. Cascais: Principia, 2012.

RATZINGER, J. "Dogmatische Konstituition über die göttliche Offenbarung". In: RAHNER, K. (Org.). Lexikon für Theologie und Kirche. V. 12. Freiburg: Herder, $1964^{2}$, pp. 498-528. 570-581.

RATZINGER, J. "A relação entre o Magistério e a Igreja e a Exegese, a cem anos da constituição da Pontifícia Comissão Bíblica". Disponível em: <http://www.vatican.va/roman_curia/ congregations/cfaith/pcb_ documents/rc_con_cfaith_doc_20021030_ratzinger_it.html $>$. Acesso em 10 de agosto de 2017.

RATZINGER, J. "Schriftauslegung im Widerstreit. Zur Frage nach Grundlagen und Weg der Exegese heute”. In: RATZINGER, J. (Org.), Schriftauslegung im Widerstreit. Freiburg im Breisgau - Basel - Wien: Herder, 1989, pp. 20.34-44.

REISER, M. Bibelkritik und Auslegung der Heiligen Schrift. Tübingen: Mohr Siebeck, 2007. 
Doutora em Teologia Bíblica pela Pontificia Università Gregoriana

(Roma)

Docente de Sagrada Escritura na Pontifícia Universidade Católica do Rio de Janeiro

Rio de Janeiro / RJ - Brasil

E-mail:mllima@puc-rio.br

Recebido em: 20/10/2017

Aprovado em: 11/12/2017 